\title{
Editorial: The pooling principle
}

\author{
Pensions (2006)12, 1-3. doi:10.1057/palgrave.pm.5950043
}

That we in the UK have something of a pensions crisis at the moment is hardly news. Couched as it often is, however, in terms such as 'we're not saving enough', the debate has become mired in individualism. What can be done to 'incentivise' individuals to save more for their retirement? Isn't the State pension credit a disincentive? Is it worth saving if you're earning less than the national average? What about contracting-out - should I contract back in? Anxieties provoked by such questions exacerbate a kind of introspective paralysis. Presently we're expecting that the next Pensions Bill - one of two due some time in 2007 - will reform the State pension system. It remains to be seen exactly what, how and when the Government will choose. At least, though, there seems to be a consensus that State pension reform, preferably radical, is a necessary precursor for any further changes to private pensions.

For nearly 30 years the watchword has been 'choice': one of those motherhood-and-apple-pie words universally deemed to be A Good Thing. Arguably not, though, where pensions are concerned. Ever since the introduction over 40 years ago of contracting-out — an idea memorably described by one prominent commentator as something that should have been strangled at birth - we have been divided by choices made about pensions. This process was made a great deal worse with the creation in 1988 of the protected rights alternative route for contracting-out. Inevitably, as this choice was largely left up to the individual to make, many made a decision which (sometimes with the benefit of hindsight) was not in their best interests. A new word, 'mis-selling', entered the lexicon. Almost 20 years later, a different Government has finally realised it's time this method of contracting-out was abolished though maybe not before 2012. There is even talk that defined benefit contracting-out should go too. The phrase 'final nail in the coffin' has been uttered so many times it has become a well-worn cliche, but the impact of such a move on administration, funding and member communications costs for DB schemes would certainly be significant.

Contracting-out is merely the most egregious of the many choices presented about pensions in recent decades. Increasingly, people have been taking the default route, that is not to save in any pension arrangement. This tendency has grown in parallel with the rate of closure of defined benefit schemes. There is abundant evidence that individuals satisfy more immediate demands upon available money - disposable income, if you like - ahead of saving for an indeterminable future. Often, there is nothing left for a pension contribution. (The proportion of self-employed people contributing to a pension fell from 64 per cent in 1988 to 49 per cent in 2004, according to the ONS. Among employees the picture is not much different, with fully onethird not belonging to any pension scheme, occupational or personal, in 2003.)

Even where money might be available, the multiplicity of options can paralyse decision making. Research from the developing field of behavioural finance has shown that the likelihood of a decision being made at all can be inversely proportional to the number of choices. ${ }^{1}$ The oftrepeated mantra 'past performance is no guide to the future' is well said, but what other readily available basis for decision making about the future is any more rational? At the moment, the impact of means-testing on state benefit entitlement looms large in the minds of potential savers (and their advisers, it would seem), as they assume that the status quo (whereby income from private pensions reduces entitlement to state benefits) will still operate when they retire.

If it were not so serious it would be laughable that each person should make an individual decision about how their life should be paid for 
if and when they become inactive economically (defined as ceasing to provide goods or services to others for monetary remuneration). Formerly known as retirement, when or if this will happen is itself increasingly questionable. As recently as 15 years ago, the possibility of deriving an income purely from working with a computer, in the form of a web-based business, did not exist because the world wide web had not been invented. Twenty-five years ago nobody worked with their own computer because the PC didn't exist. The use of computers at work in any form is still well within living memory of today's workforce.

This is merely to underline the increasing difficulty of making decisions under uncertainty about the future. Some things can be said with near-certainty, however. The world population has doubled to over $6 \mathrm{bn}$ in the last 40 years and will continue to increase for the foreseeable future. Pressure upon finite resources results either in a shrinking minority becoming relatively richer and a growing majority ever more desperate and destitute, or a more equal sharing. This author believes attempts to shore up our privileged existence are ultimately doomed by the declining volume of employment in labour-intensive processes at the same time as the number of people requiring a source of income is increasing. At the moment and for the foreseeable future, it is arguable that we cannot afford our standard of living. If we are not living on borrowed time we are certainly living on borrowed money.

However, much we might like to feel we are in control of our own destiny, all but the infinitesimal number of us who are genuinely self-sufficient are dependent on others for goods and services. It's called 'the community', or on a larger scale, 'society' (notwithstanding a notorious denial). The fact that a bin-man or sewage worker is paid much less than an investment banker or derivatives trader is no measure of the relative importance to the rest of us of the work they do (some might argue there's an inverse relationship, but let that pass). In an era when the notion of 'human rights' has become enshrined in national as well as international law, we should be able to agree to pool our skills and resources to support one another when (or if) we can no longer contribute. That might seem trite, too, but already the basic state pension for a single person has declined to around 15 per cent of national average earnings. Add to that the decline in the households' savings ratio (from 10 per cent in 1995 to just 4.4 per cent in 2004) and the support ratio (earners: pensioners, expected by the ONS to fall from 3.33 in 2004 to 2.62 by 2031), plus more of us living longer, and indeed there is a crisis.

How likely is it that the future - even just of those already in the UK workforce - can be comfortably assured if each one of us makes an individual decision? (Note that even the present Government proposals for 'personal accounts', modest as they are with a total contribution rate of 8 per cent, still incorporate numerous choices to be made and various opt-outs. Note, too, the continuing addiction to individual choice represented by the very name of the Government's chosen vehicle for encouraging pension saving.) No, the future of our society depends upon a consensual recognition that for the past 30 years we have been chasing down a blind alley, deluding ourselves that each one can command and control our own little minieconomy. We must revert to a renewed adherence to the pooling principle upon which human society was founded. Accidents of birth, gender allocation, early development, parental income, family size, etc not only should not but ultimately cannot determine resource allocation in human society.

Unfortunately, the logical conclusion - a 'citizen's pension', payable to all on an agreed residency basis (eg subject to a minimum number of years residence in the community) and at a level agreed as a decent minimum - has just been rejected by the UK Government as 'unaffordable'. In addition, it is said to be contrary to the cherished principle that a state pension should be delivered in proportion to national insurance contributions paid (or deemed to have been paid). Could it be that the very simplicity of this broad-brush idea offends the British bureaucratic mind? 
This rejection begs all sorts of questions, including whether the Government had calculated the increase in basic state pension attainable if the contributions planned for personal accounts are paid instead to national insurance. There are also unrecognised or inadequately recognised crosssubsidies in the pay-as-you-go basis of the UK national insurance system. For example, not every one of today's workers is providing a child, in addition to the contributions he or she pays, from whose earnings his or her own pension will be notionally paid in years to come. As any parent will tell you, whatever money emerges from the complex Government maze of child benefit and tax credits does not come close to covering the true cost of raising a child.

It has been clear for years that hardly any individual in the UK enjoys an income large enough to provide for a pension at the level of national average earnings, ${ }^{2}$ which surveys often suggest is a rough measure of aspirations. There is - or was - a chance, if supplemented by generous employer contributions. That possibility too is disappearing over the horizon as companysponsored pension schemes close with increasing frequency. Eight per cent (4 per cent employee, 3 per cent employer, 1 per cent tax relief) of annual earnings, as proposed by the Government for 'personal accounts', cannot possibly meet individuals' present expectations in retirement. We have a long way to go. Time is short, and the water rises. Do we have a choice?

Ian Neale

Director

Aries Pension \& Insurance Systems Ltd.,

\section{References}

1 Mitchell, O. S. and Utkus, S. P. (2004) 'Pension Design and Structure: New Lessons from Behavioural Finance', Oxford University Press, Oxford, UK (reviewed in Pensions, Vol. 10, No. 2, pp. 186-189.

2 Neale, I. M. (2000) 'Re-framing'The Annuity Problem': Can we afford retirement?’ Pensions, Vol. 5, No. 4, pp. 285-291. 